\title{
PREVENTION OF CORRUPTION BEHAVIOR IN SD CHILDREN THROUGH 7 POE ATIKAN CHARACTER EDUCATION: QUALITATIVE STUDY
}

\author{
Deri Fadly Pratama1, Jajang Bayu Kelana ${ }^{2}$, Galih Dani Septian Rahayu ${ }^{3}$ \\ ${ }^{1}$ Institut Keguruan dan Ilmu Pendidikan Siliwangi \\ ${ }^{2}$ Institut Keguruan dan Ilmu Pendidikan Siliwangi \\ ${ }^{3}$ Institut Keguruan dan Ilmu Pendidikan Siliwangi \\ ${ }^{1}$ de_fadz@ikipsiliwangi.ac.id, ${ }^{2}$ jajang-bayu@ikipsiliwangi.ac.id, ${ }^{3}$ galih040990@ikipsiliwangi.ac.id
}

\begin{abstract}
This research was conducted in general with the aim of analyzing the 7 poe atikan of character education in elementary schools in an effort to prevent corrupt behavior in elementary school children. The specific purpose of this study was to find out all students who know about corruption in elementary school-age children and to know the impact of character education on corrupt behavior among elementary school students. This research was conducted using a qualitative descriptive method with instruments used in the form of questionnaires and interviews. The subjects in this study were 30 students of grade V SDN 8 Ciseureuh Kahuripan Pajajaran. The results of this study indicate that grade V students have seen several activities in daily life including positive and negative attitudes related to corrupt behavior and character education which have a positive impact on students 'understanding related to students' understanding of corrupt behavior and methods. avoid the behavior. The conclusion from this research is that 7 points of character education can have a positive impact in preventing corrupt behavior among elementary school students.
\end{abstract}

Keywords: Corruption, Character education, 7 poe atikan

\begin{abstract}
Abstrak
Penelitian ini dilakukan secara umum bertujuan menganalisis penerapan pendidikan karakter 7 poe atikan di Sekolah Dasar (SD) dalam upaya mencegah perilkau korupsi pada anak SD. Tujuan khusus penelitian ini yaitu untuk mengetahui seberapa besar siswa mengetahui tentang perilaku korupsi yang dilakukan pada anak usia Sekolah Dasar dan untuk mengetahui dampak dari pendidikan karakter terhadap pencegahan perilaku korupsi pada siswa SD. Penelitian ini dilakukan dengan menggunakan metode deskriptif kualitatif dengan instrumen yang digunakan berupa angket dan wawancara. Subjek pada penelitian ini adalah 30 siswa kelas V SDN 8 Ciseureuh Kahuripan Pajajaran. Hasil penelitian ini menunjukan bahwa siswa kelas V sudah mengetahui beberapa kegiatan dalam kehidupan sehari-hari yang termasuk pada sikap positif dan sikap negatif berkaitan dengan perilaku korupsi serta pendidikan karakter memberikan dampak positif terhadap pemahaman siswa terkait dengan pemahaman siswa tentang perilaku korupsi dan cara-cara menghindari perilaku tersebut. Simpulan dari penelitian ini yaitu pendidikan karakter 7 poe atikan mampu memberikan dampak positif dalam pencegahan perilaku korupsi pada siswa SD.
\end{abstract}

Kata Kunci: Korupsi, Pendidikan karakter, 7 poe atikan

\section{INTRODUCTION}

Education is an experience or learning that is not only limited to schools but in various environments, both family, school and community (Andresen, Boud, \& Cohen, 2020); (Liepa \& Špona, 2015). Education can last a lifetime and affect individual development (Turner, 
2018). Education is a lifelong process in which school is only a small but necessary part (Hanemann, 2015); (Buli-Holmberg \& Jeyaprathaban, 2016);(Kelana \&Wardani, 2021).

In the educational process, it is necessary to have a disciplined attitude that is embedded in students, teachers, and school officials. Therefore, discipline must be applied to every school so that learning in schools can run according to the school's vision and mission (Baumann \& Krskova, 2016) (Anyon et al., 2016). The teacher is a measure for the creation of discipline for students. Therefore, teachers must be able to apply discipline well, both in learning and in student behavior (Gregory, Clawson, Davis, \& Gerewitz, 2016).

Discipline can be interpreted as a form of self-awareness that appears in the form of encouragement to follow and obey the rules and values and laws that apply in a certain environment (Mukodi, Burhanuddin, \& Haryono, 2019); (Sarmini, Made Swanda, \& Nadiroh, 2018). Thus, the discipline has a very important role in the process of forming children's character.

One example of behavior in everyday life that is related to discipline is that in play activities children often forget time, forget to eat, forget to go home, forget to do assignments, and so on (Alexander, Naylor, \& Saunders, 2013 ). If this happens too often, it will become a bad habit in children's development (Grusec, Danyliuk, Kil, \& O'Neill, 2017); (Wang \& Kenny, 2014). If a disciplined attitude has been well instilled in children since childhood, when they grow up, they will indirectly become obedient and obedient to the rules that apply either in the family, school, or community environment (Lansford \& Deater-Deckard, 2012).

Likewise, if a child is not instilled in a disciplined attitude since childhood, when he grows up he will become someone who leads to behavior that violates the rules in other words leading to corrupt behavior (Gershoff et al., 2010). Because corruption is not only related to stealing money, but every rule that is violated is a form of corrupt behavior, including often arriving late, playing until forgetting time, neglecting duties, cheating is the seeds of corrupt behavior. Thus, the importance of instilling the value of discipline from an early age starting from the family environment, the school environment, and the community environment to form children or individuals who are obedient and obedient to the rules and values that apply so that they can stay away from all forms that lead to corrupt behavior (Naylor \& Saunders, 2009).

Another thing that underlies this research is the results of previous research such as research by Sakinah \& Bakhtiar (2019) with the title of the anti-corruption education model in elementary schools in realizing a clean generation and integrity from an early age with qualitative research methods whose research results are based on the results of a literature 
review. anti-corruption education models can be developed with various methods of learning. The second research, namely research by Mustofa \& Akhwani (2019) on the strategy of inculcating anti-corruption values in elementary schools (SD) with the results of the research is that there are three strategies for cultivating anti-corruption values in elementary schools, namely integration with subjects, habituation in students' daily lives. , and by modeling by teachers. The third research is research by (Izzah, 2019) with the title of fostering anticorruption values in children to shape character through seedling games at MDTA Pekanbaru, whose research results are changes in behavior in a positive direction such as discipline in clean Saturday activities, decreasing the number of students who is late, and the emergence of the students' self-confidence when carrying out tests and competitions.

Based on the results of these studies, there are still gaps regarding research related to anti-corruption in elementary schools such as in the first and second research, namely the research is still a literature study, the second research was carried out on elementary schoolaged children but not in the elementary environment, therefore research with the title of prevention was carried out. Corrupt behavior in elementary school children through character education to analyze the application of 7 points of character education to prevent anticorruption behavior at SDN 8 Cisereuh Kahuripan Pajajaran.

\section{METHOD}

This type of qualitative research is used which is located at SDN 8 Cisereuh Kahuripan Pajajaran Purwakarta. Qualitative research is a method used by researchers (Fauzia \& Kelana, 2020). The subjects of this study were 30 students of class V. The instruments used in this study were questionnaire sheets and interview sheets. On the questionnaire sheet, there are 20 checklist-form statements and there are three alternative answers to each statement, namely "Often, Sometimes, and Never". In each statement is divided into positive statements and negative statements.

The data analysis technique carried out in this research is descriptive qualitative by describing the data and making conclusions that are interpreted in the form of a sentence statement. 


\section{RESULTS AND DISCUSSION}

\section{a. Analysis and Problem Solving of Corruption in Elementary School Children}

Based on the results of research through questionnaires and interviews, almost all students know about the behavior of corruption, but what they know is only corruption in the form of money, while acts of corruption in simple matters they do not know about it even without realizing it has been done.

Forms of behavior that lead to seeds of corruption in elementary school-age children, such as the habit of littering, cheating, arriving late, having disagreements with friends, and so on (Izza, 2019); (Collins, McMullen, \& Reutzel, 2016). Based on the results of the data obtained through a questionnaire that has been filled by students, it reflects the existence of positive attitudes and negative attitudes towards anti-corruption behavior of elementary schoolaged children. Following the data obtained based on statements related to anti-corruption behavior in elementary school-aged children, there was $98.61 \%$, namely the behavior of students who often participated in flag ceremonies every Monday. This shows that the fifthgrade students of SDN Ciseureuh 8 Kahuripan Pajajaran Purwakarta Regency have a high sense of nationalism and fulfill their duties as a student in carrying out flag ceremonies every Monday. Judging from the negative side, $52.78 \%$ of students' discipline attitude is still low in playing until they forget time. Seeing the results of the observations, the fifth-grade students of SDN Ciseureuh 8, Purwakarta Regency, it is necessary to instill the value of anti-corruption education from childhood to form the personality of children who behave anti-corruption starting from the family environment, school, and the general environment. anti-corruption behavior cannot be instilled if it is not set by example or by example. This exemplary not only comes from the family environment but from the government also plays a role in instilling anticorruption behavior (Howe, 2016); (Sutherland \& Markauskaite, 2012). For example, through a school curriculum that includes character subjects because educating is not only to make students smart in their cognitive ways but to have noble character. Following are the results of the diagram of the results from the questionnaire sheets that have been filled in by grade $\mathrm{V}$ SDN Ciseureuh 8 Purwakarta Regency: 


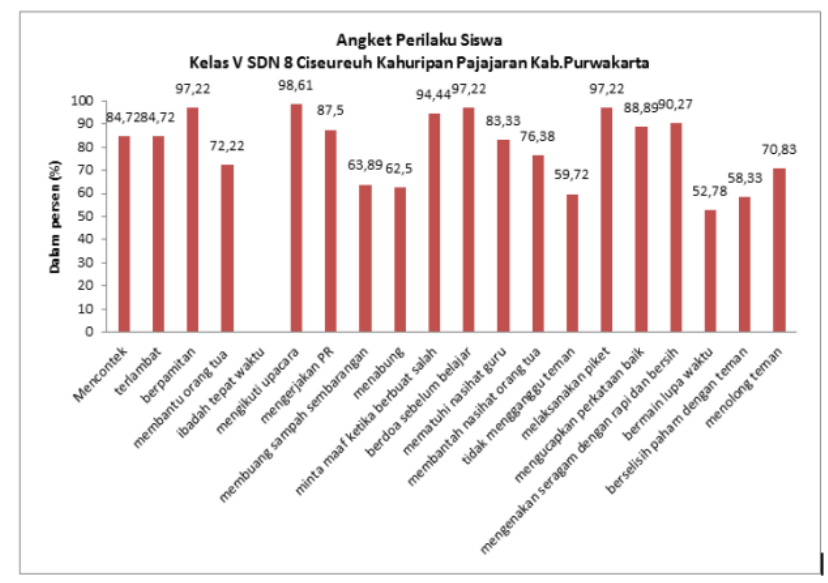

Figure 1. Diagram of the results of the Student Behavior Questionnaire

\section{b. Efforts to Improve Discipline of Elementary School Children in Playing Activities}

Based on the observations of grade V SDN Ciseureuh 8, Purwakarta Regency, the level of student discipline is still low at $52.78 \%$ in terms of playing and forgetting time. Therefore, there needs to be an effort to improve children's discipline. The things that affect the low level of discipline of children in playing are environmental factors or social factors and parenting styles. environmental factors greatly affect children in playing and electronic media such as the internet also affects them as a means of playing so that children forget time, forget about their duties, forget to do homework, and so on (Pea et al., 2012); (Liu \& Wang, 2016).

A discipline is a form of obedience and obedience to applicable regulations without coercion. However, in reality, many students behave in a disciplined manner based on the rules that restrict them. The result of this research is the low level of student discipline. The attitude of discipline can shape the individual's psyche to understand the rules so that he will understand when is the right time to obey the rules. Therefore, efforts to educate children to have a disciplined attitude must fulfill the disciplinary elements as stated by (Hurlock, 2014) as follows:

1. Regulations

2. Punishment

3. Awards

\section{Consistency}

After the disciplinary elements are fulfilled at home or school, it will be easier to form a child's personality to have a disciplined attitude because the child is accustomed to disciplinary matters. Thus, there is a need for habituation in educating children to achieve disciplined personalities. 


\section{c. The Importance of Play Activities for Children}

Playing activities are a necessity for children so that children cannot be separated from playing activities (Bobby Saragih \& Tedja, 2018). Through play, children can develop their creativity and abilities and explore new things according to their experiences because children can build their knowledge through social interactions (Smart, 2012) (Kelana \& Pratama, 2019). Thus, playing is very necessary for children, but it cannot be separated from the role of parents who must always pay attention to every child's play activities so that they are not excessive and children can still play but still have a disciplined attitude that has been embedded through habitual disciplinary behavior.

\section{CONCLUSION}

Based on the results of research on the fifth-grade students of SDN Ciseureuh 8, Purwakarta Regency, there are three things to be concluded: First, the importance of planting the value of anti-corruption education in children. If a child has been instilled in anti-corruption behavior from a young age, then when he grows up he will have anti-corruption behavior so he knows right and deviant behavior. Second, efforts to improve students' disciplinary attitude in playing activities both at home and at school. A disciplined attitude needs to be instilled in the child to form a person who is obedient and obedient to the rules with full awareness without any element of coercion. Third, the importance of play activities for children is an activity that can never be separated from children. Through play, children will be able to explore and even develop their abilities by playing through social interactions with both peers and adults. It's just that there needs to be attention and supervision from parents so that children keep playing but not too much. The recommendations for further research are expected to be carried out with more diverse subjects and with more in-depth data collection so that the research results can be generalized more broadly and it is hoped that the results of this study will become a reference source for further research so that there is research in the form of giving treatment especially in preventing corrupt behavior in students. SD.

\section{ACKNOWLEDGMENTS}

Thanks to RISTEKDIKTI for providing research funding through the beginner lecturer research program (PDP) so that this research can be carried out smoothly according to targets and objectives. 
Journal of Elementary Education

Volume 5, Number 1, February 2021
P-ISSN: 2580-9326

E-ISSN: 2580-7714

\section{REFERENCES}

Alexander, R., Naylor, B., \& Saunders, B. J. (2013). Lawful Correction or Child Abuse: Clarifying the Boundaries, Sanctions and Decision-Making Surrounding the Physical Discipline of Children. SSRN Electronic Journal. https://doi.org/10.2139/ssrn.2322317

Andresen, L., Boud, D., \& Cohen, R. (2020). Experience-based learning. In Understanding Adult Education and Training. https://doi.org/10.4324/9781003118299-22

Anyon, Y., Gregory, A., Stone, S., Farrar, J., Jenson, J. M., McQueen, J., ... Simmons, J. (2016). Restorative Interventions and School Discipline Sanctions in a Large Urban School District. American Educational Research Journal. https://doi.org/10.3102/0002831216675719

Baumann, C., \& Krskova, H. (2016). School discipline, school uniforms and academic performance. International Journal of Educational Management. https://doi.org/10.1108/IJEM-09-2015-0118

Bobby Saragih, J. F., \& Tedja, M. (2018). How children create their space for play? IOP Conference Series: Earth and Environmental Science, 109(1). https://doi.org/10.1088/1755-1315/109/1/012045

Buli-Holmberg, J., \& Jeyaprathaban, S. (2016). Effective practice in inclusive and special needs education. International Journal of Special Education.

Collins, J. D., McMullen, J. S., \& Reutzel, C. R. (2016). Distributive justice, corruption, and entrepreneurial behavior. Small Business Economics. https://doi.org/10.1007/s11187016-9751-8

Fauzia, N. L. U., \& Kelana, J. B. (2020). Natural Science Problem Solving in Elementary School Students Using the Project Based Learning (PjBL) Model. Jurnal Ilmiah Sekolah Dasar, 4(4).

Gershoff, E. T., Grogan-Kaylor, A., Lansford, J. E., Chang, L., Zelli, A., Deater-Deckard, K., \& Dodge, K. A. (2010). Parent discipline practices in an international sample: Associations with child behaviors and moderation by perceived normativeness. Child Development. https://doi.org/10.1111/j.1467-8624.2009.01409.x

Gregory, A., Clawson, K., Davis, A., \& Gerewitz, J. (2016). The Promise of Restorative Practices to Transform Teacher-Student Relationships and Achieve Equity in School Discipline. Journal of Educational and Psychological Consultation. https://doi.org/10.1080/10474412.2014.929950

Grusec, J. E., Danyliuk, T., Kil, H., \& O’Neill, D. (2017). Perspectives on parent discipline and child outcomes. International Journal of Behavioral Development. https://doi.org/10.1177/0165025416681538 
Hanemann, U. (2015). Lifelong literacy: Some trends and issues in conceptualising and operationalising literacy from a lifelong learning perspective. International Review of Education. https://doi.org/10.1007/s11159-015-9490-0

Howe, E. R. (2016). Exemplary teacher induction: An international review. In In Search of Subjectivities: An Educational Philosophy and Theory Teacher Education Reader, Volume II. https://doi.org/10.1111/j.1469-5812.2006.00195.x

Hurlock, E. (2014). Perkembangan Anak Edisi Keenam Jilid I. Jakarta. In Penerbit Erlangga.

Izza, L. (2019). MENUMBUHKAN NILAI-NILAI ANTI KORUPSI PADA ANAK UNTUK MEMBENTUK KARAKTER MELALUI “SEMAI GAMES” DI MDTA RABITHATUL ULUM PEKANBARU. Psychopolytan : Jurnal Psikologi.

Izzah, L. (2019). Menumbuhkan Nilai-Nilai Anti Korupsi Pada Anak Untuk Membentuk Karakter Melalui “Semai Games ” Di. 2(2), 84-95.

Kelana, J. B., \& Wardani, D. S. (2021). MODEL PEMBELAJARAN IPA SD. Cirebon: Edutrimedia Indonesia.

Kelana, J. J. B., Kelana, J. B., \& Pratama, D. F. (2019, December). Improving the Capability of Prospective Primary School Teachers in Making Science-Based Science Teaching Materials Based on ICT Media Assisted Literacy. In 5th International Conference on Education and Technology (ICET 2019) (pp. 1-4). Atlantis Press. Lansford, J. E., \& Deater-Deckard, K. (2012). Childrearing discipline and violence in developing countries. Child Development. https://doi.org/10.1111/j.1467-8624.2011.01676.x

Liepa, D., \& Špona, A. (2015). Teaching and Learning in Higher Education. SOCIETY, INTEGRATION, EDUCATION. Proceedings of the International Scientific Conference. https://doi.org/10.17770/sie2014vol1.740

Liu, T., \& Wang, H. (2016). The influence of Internet plus the era of bad social ideological trend for college student and the study of countermeasures. https://doi.org/10.2991/amahs-16.2016.89

Mukodi, Burhanuddin, A., \& Haryono. (2019). Anti Corruption Perception and Modeling: A Critical Study among Educational Institutions in Pacitan, Indonesia. Journal of Physics: Conference Series. https://doi.org/10.1088/1742-6596/1254/1/012010

Mustofa, \& Akhwani. (2019). Strategi Penanaman Nilai-Nilai Antikorupsi di Sekolah Dasar. Education and Human Development Journal, 5(1), 43-60. https://doi.org/10.33086/ehdj.v5i1.1301

Naylor, B., \& Saunders, B. (2009). Whose rights? Children, parents and discipline. Alternative Law Journal, 34(2), 80-85. https://doi.org/10.1177/1037969X0903400202 
Journal of Elementary Education

Volume 5, Number 1, February 2021
P-ISSN: 2580-9326

E-ISSN: 2580-7714

Pea, R., Nass, C., Meheula, L., Rance, M., Kumar, A., Bamford, H., ... Zhou, M. (2012). Media use, face-to-face communication, media multitasking, and social well-being among 8- to 12-year-old girls. Developmental Psychology. https://doi.org/10.1037/a0027030

Sakinah, N., \& Bakhtiar, N. (2019). Model Pendidikan Anti Korupsi di Sekolah Dasar dalam Mewujudkan Generasi Yang Bersih dan Berintegritas Sejak Dini. El-Ibtidaiy:Journal of Primary Education, 2(1), 39. https://doi.org/10.24014/ejpe.v2i1.7689

Sarmini, Made Swanda, I., \& Nadiroh, U. (2018). The importance of anti corruption education teaching materials for the young generation. Journal of Physics: Conference Series. https://doi.org/10.1088/1742-6596/953/1/012167

Smart, J. (2012). Friedrich Froebel. Practical Pre-School. https://doi.org/10.12968/prps.2012.1.133.12

Sutherland, L., \& Markauskaite, L. (2012). Examining the role of authenticity in supporting the development of professional identity: An example from teacher education. Higher Education. https://doi.org/10.1007/s10734-012-9522-7

Turner, J. (2018). Individual development. In Psychology for the Classroom. https://doi.org/10.4324/9781315209357-8

Wang, M. Te, \& Kenny, S. (2014). Longitudinal Links Between Fathers' and Mothers' Harsh Verbal Discipline and Adolescents' Conduct Problems and Depressive Symptoms. Child Development. https://doi.org/10.1111/cdev.12143 